\title{
Fatty Acid Distribution in Triglycerides of Yeasts Grown on Glucose or n-Alkanes
}

\author{
By R. F. THORPE AND C. RATLEDGE \\ Department of Biochemistry, The University of Hull, \\ Kingston upon Hull, Yorkshire, $\mathrm{HU}_{7}{ }_{7} \mathrm{RX}$ \\ (Accepted for publication 24 March 1972) \\ SUMMARY
}

\begin{abstract}
Lipid contents of yeasts grown on glucose were: Candida lipolytica, $5 \cdot 4 \% ; C$. tropicalis, $9.4 \%$; C. utilis, 2.7\%; Candida 107, 4I \%; Hansenula anomala, $12.5 \%$; Rhodotorula glutinis, $2 \cdot 7 \%$; and $R$. graminis, $9 \cdot 1 \%$. In each yeast about $80 \%$ of the lipid consisted of triglycerides. When the triglycerides from five of the yeasts were analysed in detail, an unsaturated acid was invariably found at the 2-position. With Candida 107 and $R$. graminis about $50 \%$ of the total triglyceride fatty acids were saturated, resulting in over $50 \%$ of the triglycerides being of the 1,3 -disaturated2-monounsaturated type. When Candida 107 and $C$. tropicalis were grown on individual $n$-alkanes, from $\mathrm{C}_{12}$ to $\mathrm{C}_{16}$, the fatty-acid composition varied according to the chain length of the substrate, although with $n$-tridecane neither yeast produced tridecanoic acid in the triglyceride and with $n$-dodecane only $C$. tropicalis contained an appreciable amount of dodecanoic acid in the triglyceride ( $32 \%$ of the fatty acids). With both yeasts on each alkane substrate, the lipid contents were not only lower than when grown on glucose but contained a smaller proportion of triglyceride. Saturated acids were now located at the 2-position of the triglycerides: Candida 107 grown on $n$-tetradecane produced $46 \%$ of its triglycerides with a saturated acid at the 2-position. The main advantage to be gained by growing yeasts on $n$-alkanes is, as far as lipid formation is concerned, the biosynthesis of specific fatty acids rather than the production of plant-like triglycerides.
\end{abstract}

\section{INTRODUCTION}

The distribution of fatty acids in the triglycerides obtained from plant oils and animal fats is known in some detail (Jurriens, I968; Fedeli \& Jacini, 197I). However, little work has been done on the composition of triglycerides derived from micro-organisms, presumably because microbial fats are not considered to be an economic source of fat (Ratledge, 1970, I97I). The present investigation was undertaken to gain knowledge in this neglected area, being stimulated by earlier work of Harries \& Ratledge (1969) who found that the distribution of fatty acids in the triglyceride fraction of a species of Candida grown on $n$-alkanes is such that the 2-position of the triglyceride is almost exclusively occupied by unsaturated acids. Although this is typical of most plant oils (Fedeli \& Jacini, 197I), the lipid of this yeast had a high proportion of symmetrical disaturated glycerides such as is found in only the commercially expensive cocoa and illipé butters (Coleman, 1963).

\section{METHODS}

Organisms and growth. The following yeasts were used: Candida lipolytica NCYC153, C. tropicalis $\mathrm{NCYC}_{4}, C$. utilis $\mathrm{NCYC} 359$, Hansenula anomala $\mathrm{NCYC} 18$, Rhodotorula glutinis NCYC 59, $R$. graminis NCYC 502. Also used was an untyped species of Candida, referred to as 
Candida 107, which has been used in previous studies related to lipid formation (see Ratledge, 1970).

For growth of yeasts on glucose, a medium was used containing: $\mathrm{KH}_{2} \mathrm{PO}_{4}, 2 \mathrm{~g} ;\left(\mathrm{NH}_{4}\right)_{2} \mathrm{SO}_{4}$, $0.5 \mathrm{~g}$; glucose (sterilized separately), $25 \mathrm{~g}$; $\mathrm{MgSO}_{4} .7 \mathrm{H}_{2} \mathrm{O}, 0.5 \mathrm{~g}$; yeast extract, $0.5 \mathrm{~g}$; distilled water to $\mathrm{I} l$ with the $\mathrm{pH}$ value adjusted to 5.5 with $\mathrm{NaOH}$. Cultures were grown in 41 conical flasks containing $\mathrm{I} .51$ medium on a gyrotary shaker at $28^{\circ} \mathrm{C}$. Candida $\mathrm{I07}$, and C. tropicalis were also grown on a medium containing: $\left(\mathrm{NH}_{4}\right)_{2} \mathrm{SO}_{4}, 2 \mathrm{~g} ; \mathrm{K}_{2} \mathrm{HPO}_{4}, 5.0 \mathrm{~g} ; \mathrm{NaCl}, 0.5 \mathrm{~g}$; $\mathrm{MgSO}_{4} \cdot 7 \mathrm{H}_{2} \mathrm{O}, \mathrm{I} \cdot \mathrm{I} \mathrm{g} ; \mathrm{CaCl}_{2} .6 \mathrm{H}_{2} \mathrm{O}, 0.5 \mathrm{~g} ; \mathrm{FeCl}_{3} .6 \mathrm{H}_{2} \mathrm{O}$, 0.0I $\mathrm{g} ; \mathrm{ZnSO}_{4} \cdot 7 \mathrm{H}_{2} \mathrm{O}, 5 \mathrm{mg}$; yeast extract, $0.5 \mathrm{~g}$; distilled water to $\mathrm{I} l$ and the $\mathrm{pH}$ value adjusted to 5.5 . The carbon source was either glucose at $25 \mathrm{~g} / \mathrm{l}$ or an $n$-alkane $\left(\mathrm{C}_{12}\right.$ to $\left.\mathrm{C}_{16}\right)$ at $10 \%(\mathrm{v} / \mathrm{v})$ final concentration. Cultures were grown at $30^{\circ} \mathrm{C}$ in $\mathrm{I} 1$ vortex-aerated fermenters similar in concept to that described by Harvey, Fewson \& Holms (1969).

Yeasts were harvested by centrifuging at $500 \mathrm{~g}$ for $20 \mathrm{~min}$. After washing with water the yeast paste was freeze-dried.

Extraction and fractionation of lipid. The method of Folch, Lees \& Sloane-Stanley (1957) was used to extract lipid from the freeze-dried yeast. The chloroform + methanol $(2: \mathrm{I}, \mathrm{v} / \mathrm{v})$ extract, after filtering from the yeast residue, was evaporated almost to dryness under reduced pressure and then partitioned between equal volumes of chloroform and water. The chloroform layer was evaporated and the residue weighed. This lipid extract was fractionated quantitatively by column chromatography on silicic acid according to the procedure of Barron \& Hanahan (1958).

Distribution of fatty acids in triglycerides. Triglycerides were purified where necessary by thin-layer chromatography on $0.5 \mathrm{~mm}$ silica-gel plates in petroleum ether (b.p. 40 to $60^{\circ} \mathrm{C}$ ) + diethyl ether + formic acid (85: 15:I, by vol.) according to Nichols \& James (I964). The technique of lipolysis as described by Coleman \& Fulton (I96I) was used to compare the fatty acids at the 2-position of the glyceride molecules with the total fatty acids. Monoglycerides were recovered by preparative thin-layer chromatography on $0.5 \mathrm{~mm}$ silica-gel plates, developed with $n$-hexane + diethyl ether + chloroform + acetic acid (40:55:5:0.2, by vol.; Desnuelle, Sari \& Entressangles, 1966). Formation of I-monoglycerides was checked by thin-layer chromatography on $5 \%$ boric acid-impregnated silica-gel $\mathrm{G}$ plates developed with chloroform + acetone + methanol + acetic acid (7I:25:4:0.13, by vol.; Thomas, Scharoun \& Ralston, 1965).

The fatty acid composition of the isolated monoglycerides and triglycerides was determined by gas chromatography (using a Wilkens 'Aerograph', Model 600-C, Wilkens Instrument \& Research Inc., P.O. Box 313, Walnut Creek, California, U.S.A.) of the methyl esters on a column $\left(5 \mathrm{ft} \times \frac{1}{8}\right.$ in) packed with diethylene glycol succinate at $185{ }^{\circ} \mathrm{C}$. Eluted compounds were identified by comparison of retention times with standard compounds. Relative proportions of fatty acids were calculated from the peak areas estimated from peak height $\times$ peak width at $\frac{1}{2}$ peak height. Methyl esters of fatty acids were formed directly from the lipid by deacylating with $0.2 \mathrm{~N}$-sodium methoxide for $\mathrm{I} h$ at room temperature under $\mathrm{N}_{2}$ (Marinetti, 1962). Triglyceride compositions were calculated from lipolysis data according to the I,3-random,-2-random distribution hypothesis of Vander Wal (1960) and Coleman \& Fulton (1961) (see also Coleman, 1963, and Vander Wal, 1964). This hypothesis assumes that the fatty acids are distributed randomly between the I- and 3-positions so that, knowing the fatty acids of the whole triglycerides and the fatty acids on the 2-position of the glyceride molecule, the triglyceride composition can be calculated.

Fractionation of triglycerides on the basis of unsaturation. This was accomplished by thinlayer chromatography on $12.5 \% \mathrm{AgNO}_{3}$ - silica-gel plates developed with chloroform + 
methanol (99.5:0.5, v/v; Barrett, Dallas \& Padley, 1962). Plates were sprayed with a $0 \cdot 1 \%$ alcoholic solution of Rhodamine $6 \mathrm{G}$ and spots visualized under u.v. radiation. Quantitative separation and estimation of each triglyceride class after elution of the bands with $5 \%$ methanol in ether $(2 \times 2 \mathrm{ml})$ was then made with a hydroxamic acid procedure (Stern \& Shapiro, I953).

Chemicals. Individual $n$-alkanes, $99.9 \%$ purity based on gas-liquid chromatography, were a generous gift from B.P. Chemicals International Ltd, Sunbury-on-Thames. Other chemicals including chromatography solvents were of highest grade commercially available and were not purified further. Pancreatic lipase was obtained from Koch-Light Laboratories, Colnbrook, Buckinghamshire.

\section{RESULTS}

Yeasts grown on glucose. The lipid contents of seven yeasts grown on glucose in shakeculture varied from $4 \mathrm{I} \%$ to $2 \cdot 7 \%$ of the total dry weight (Table 1 ). Fractionation of each lipid by column chromatography on silicic acid showed that the triglyceride + free fatty acids fraction was always the largest component (Table $I$ ). The amount of free fatty acids in this fraction was always very low, as judged from subsequent thin-layer chromatography of this fraction (probably less than $5 \%$ of the amount of triglyceride) except for Rhodotorula glutinis which contained a higher proportion of fatty acids (probably about 20 to $30 \%$ of the triglyceride amount). The appearance of free fatty acids in these lipid fractions is probably an artefact caused by action of the lipases of the organism itself during extraction (Barron \& Hanahan, 1958; Wills, 1965).

Subsequent analysis of the distribution of fatty acids in triglycerides from five of these yeasts indicated that little, if any, saturated fatty acid was incorporated into the 2-position of the triglyceride (Table 2). The fatty-acid compositions of the triglycerides from Candida lipolytica changed between the exponential and stationary phases of growth (Table 2).

From the data of Table 2 the triglyceride compositions were calculated (Table 3): with Candida 107 and Rhodotorula graminis the largest fractions were 1,3-disaturated-2-unsaturated glycerides because of the relatively high proportion of saturated acids in the total triglyceride.

Yeasts grown on n-alkanes. The appearance of fatty acids in the lipids of micro-organisms of the same chain-length as an $n$-alkane growth substrate (Davis, 1964; Ratledge, 1968) created the possibility of producing acids which are not usually found in microbial lipids. Such acids are those of a short chain-length $\left(\mathrm{C}_{12}\right.$ and $\left.\mathrm{C}_{14}\right)$ or having an odd number of carbon atoms. Accumulation of both these types of acid has already been reported (Ratledge, I970).

Of the yeasts grown on glucose, two were subsequently used for growth on individual $n$-alkanes from dodecane to hexadecane.

I. Candida 107. This yeast grew very slowly in shake-cultures with individual $n$-alkanes from $C_{12}$ to $C_{16}$ but, even in a vortex-aerated fermenter, the growth rate and final yield of biomass were less than those attainable with glucose as carbon source (Table 4). Lipid extracted with chloroform + methanol $(2: \mathrm{I}, \mathrm{v} / \mathrm{v})$ always contained some residual hydrocarbon which added to the apparent lipid content of the organism and was removed by subsequent column chromatography.

Fractionation of the lipids from the organism grown on the various alkanes showed that, although the triglycerides still constituted the major fraction, their relative proportion was less than when glucose was the growth substrate. Loss in triglycerides was compensated for by corresponding increases in the phospholipids (Table 4). The fatty acids of the whole 


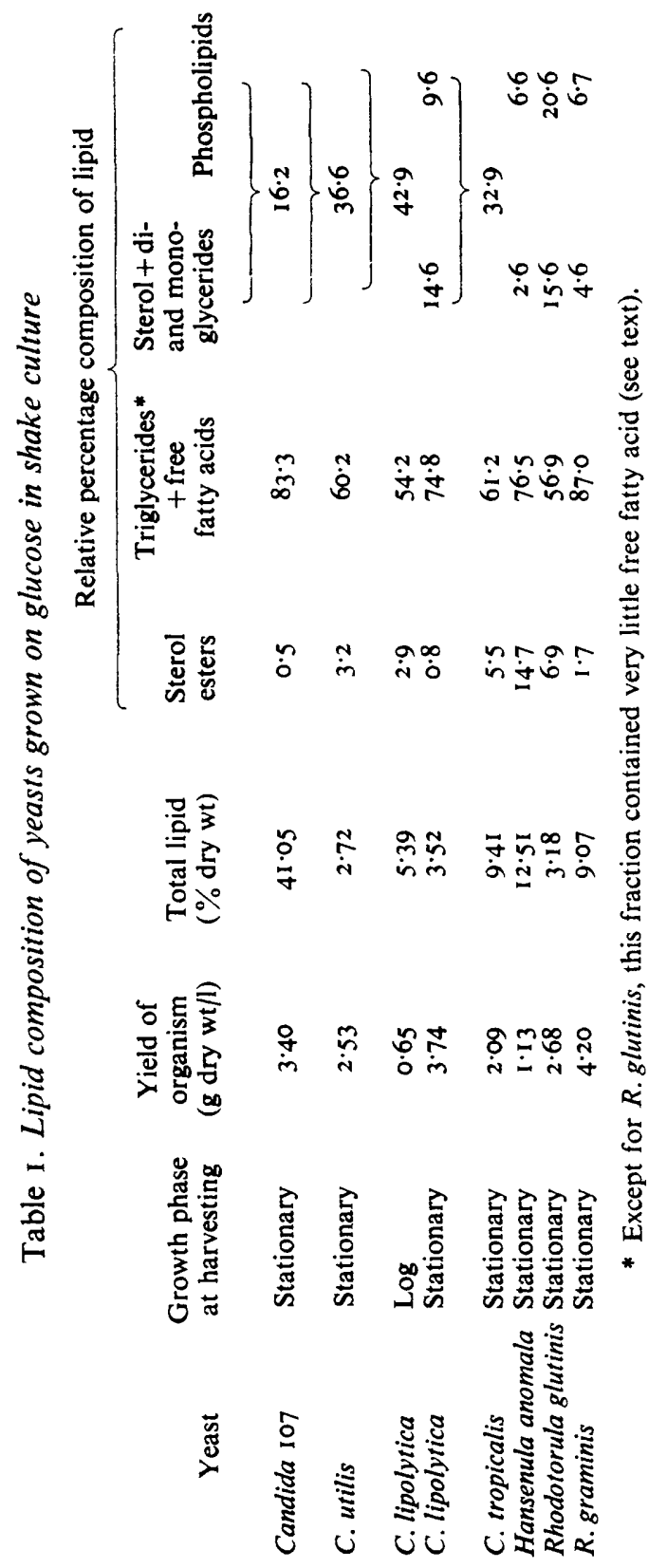




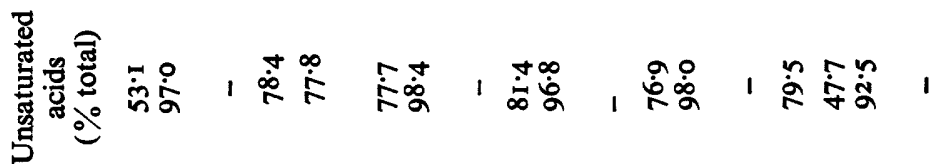

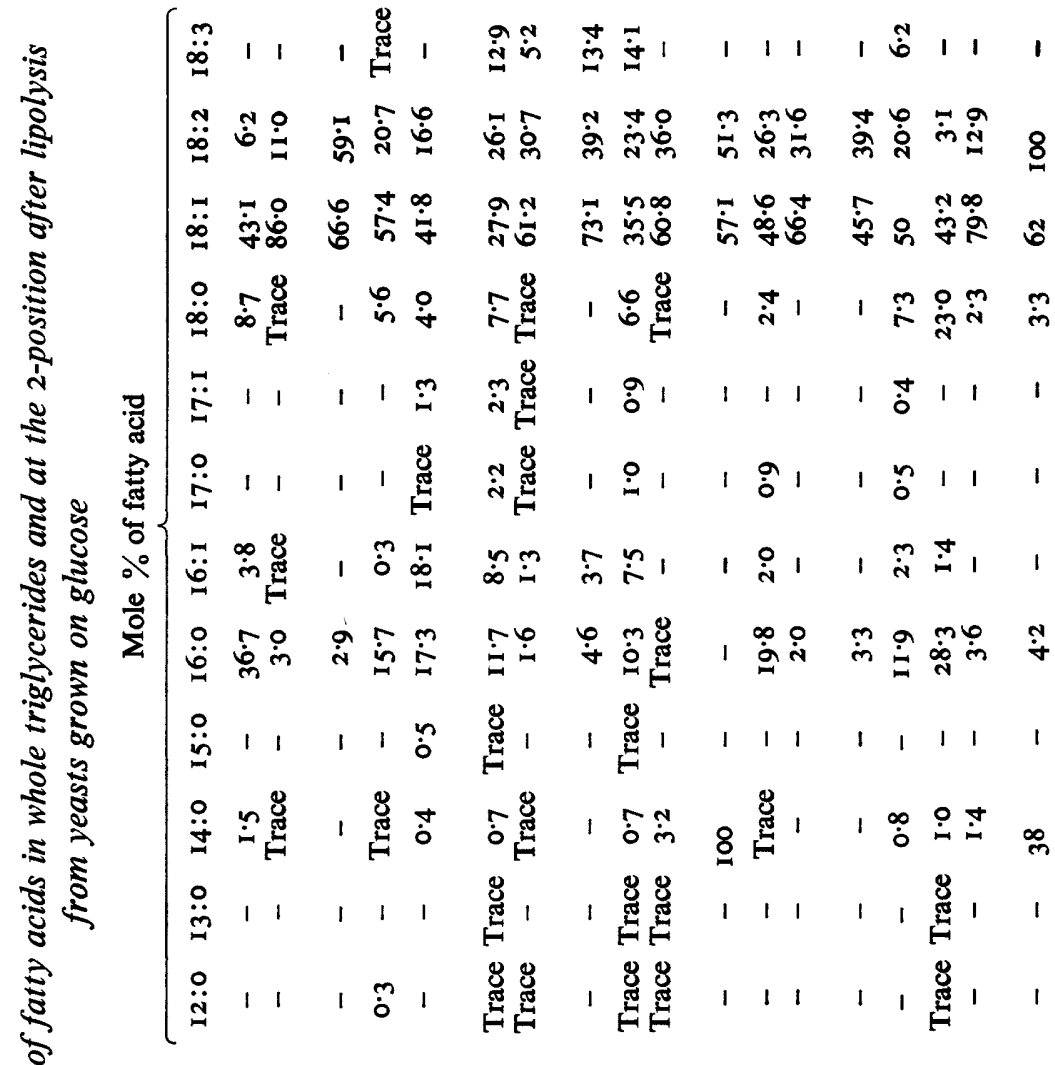

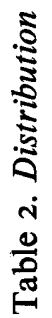

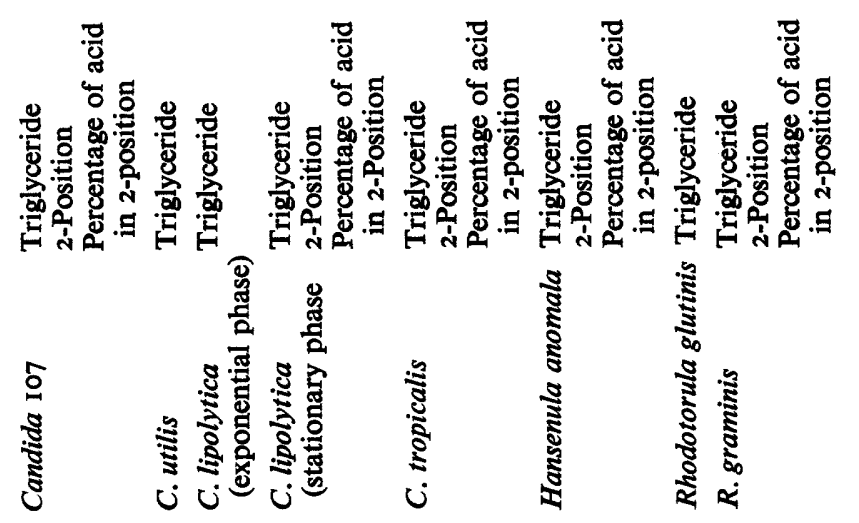


Table 3. Calculated triglyceride compositions in yeasts grown on glucose to stationary phase

\begin{tabular}{lrrrrrr}
\multicolumn{7}{c}{ Triglyceride fraction* } \\
Yeast & SSS & SSU & SUS & USU & SUU & UUU \\
Candida 107 & $1 \cdot 4$ & $1 \cdot 4$ & $50 \cdot 0$ & 0.3 & $39 \cdot 0$ & $7 \cdot 9$ \\
C. lipolytica & 0.3 & $1 \cdot 0$ & $11 \cdot 9$ & 0.8 & $44 \cdot 2$ & 41.6 \\
C. tropicalis & 0.3 & $1 \cdot 2$ & $7 \cdot 0$ & $1 \cdot 6$ & $38 \cdot 0$ & $51 \cdot 9$ \\
Hansenula anomala & 0.3 & 0.8 & $11 \cdot 2$ & 0.8 & $44 \cdot 0$ & $42 \cdot 9$ \\
Rhodotorula graminis & 4.0 & $2 \cdot 0$ & $52 \cdot 7$ & 0.5 & 35.0 & 5.8
\end{tabular}

* Triglycerides are classed as trisaturated (SSS); 1,2-disaturated-3-monounsaturated glycerides (SSU); 1,3-disaturated-2-monounsaturated glycerides (SUS); 1,3-diunsaturated-2-monosaturated glycerides (USU); 1,2-diunsaturated-3-monosaturated glycerides (SUU); and triunsaturated (UUU). The unsaturated acids, palmitoleic (I6:I), oleic (18:1), linoleic (18:2) and linolenic (I8:3) acids are not distinguished.

triglycerides and in the 2-position were determined except when tridecane had been used as growth substrate (Table 5). As may have been expected, the fatty acid composition varied according to the particular $n$-alkane used as growth substrate. Surprisingly, however, the triglycerides from the yeast grown on $n$-tetradecane and $n$-pentadecane contained appreciable amounts of saturated acids in the 2-position so that, upon calculating the triglyceride composition (Table 6), a much higher content of trisaturated trigylceride than usual was indicated.

2. Candida tropicalis. This yeast grew faster than Candida 107 on all $n$-alkanes used, attaining a high final yield but always with a lower lipid content (Table 7). The proportion of triglyceride in the lipid was generally low. This was compensated for by an increase in sterol content but with $n$-pentadecane as substrate over $50 \%$ of the total lipid was phospholipid (Table 7). The fatty acids in the triglyceride molecules, like those of Candida 107, varied according to the chain-length of the $n$-alkane growth substrate (Table 8 ). There was one notable difference between the two yeasts in that, with $n$-dodecane as substrate, $C$. tropicalis produced $32 \%$ lauric acid within the triglyceride whereas with Candida 107 the amount was less than I \%. From the fatty acid composition at the 2-position in the triglycerides (Table 8) the triglyceride compositions could be calculated (Table 9). Sufficient material to enable accurate analyses to be completed was available only with the triglycerides extracted from $C$. tropicalis grown on $n$-tetradecane, $n$-pentadecane and $n$-hexadecane.

Verification of 1,3-random-2-random distribution hypothesis. There was good agreement between the experimental values obtained for Candida 107 growth on either glucose or $n$ tetradecane and those calculated according to the hypothesis advanced independently by Vander Wal (1960) and Coleman \& Fulton (196I) (Table 10). As this hypothesis has already been verified with many different types of animal and plant triglycerides (Coleman, 1963; Vander Wal, 1964) and is also applicable to the yeast Candida 107 grown on two different types of substrate, we have not repeated this procedure of verification with the other yeasts studied here.

\section{DISCUSSION}

Five yeasts, from three genera, when grown on glucose, produced triglycerides containing almost entirely unsaturated fatty acids in the 2-position. This is similar to triglycerides from plant sources (Vander Wal, 1964). Rhodotorula graminis and Candida 107 produced an unusually high proportion of saturated fatty acids in the lipid (52\% and $46 \%$ respectively) which, therefore, led to a high content of 1,3 -disaturated-2-monounsaturated triglyceride in 


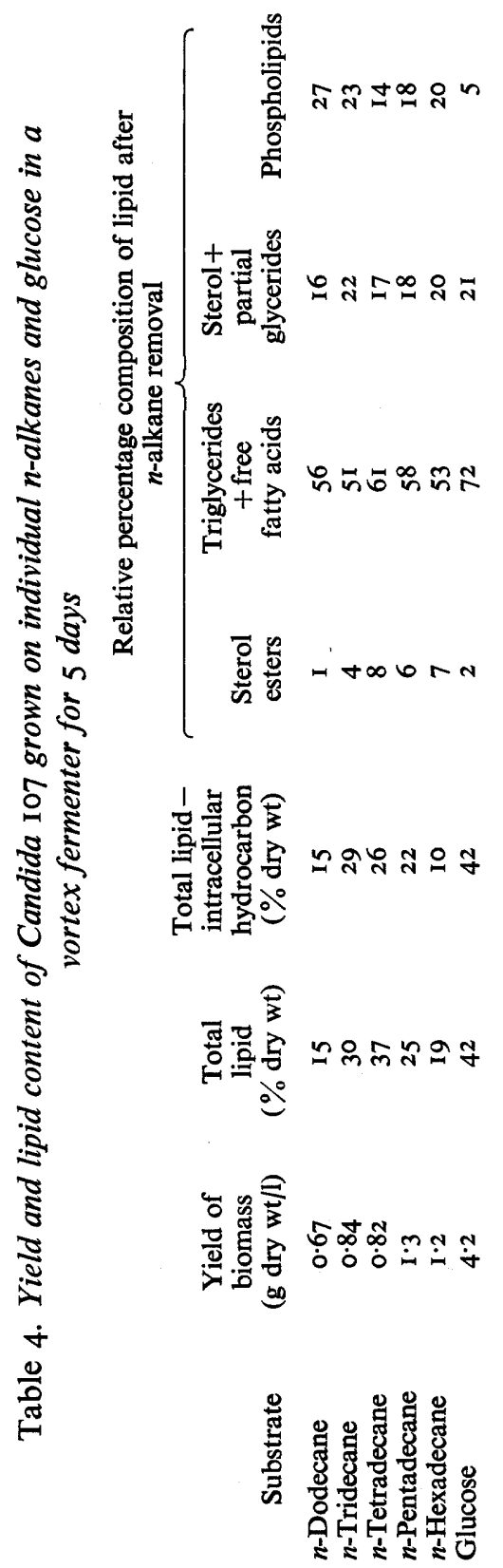




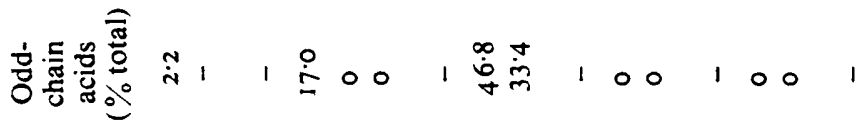

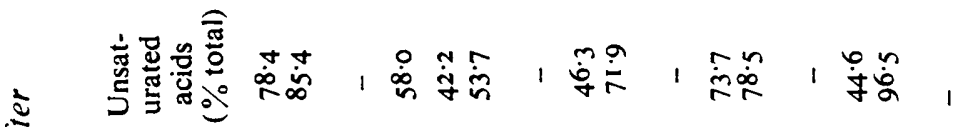

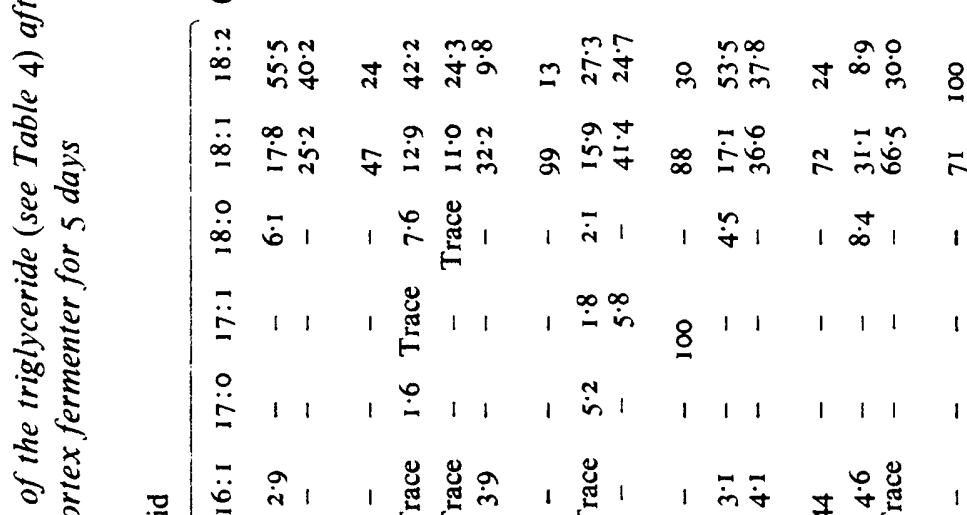

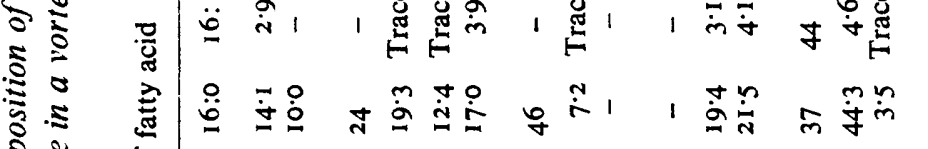
i

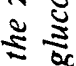
¿ 2 i



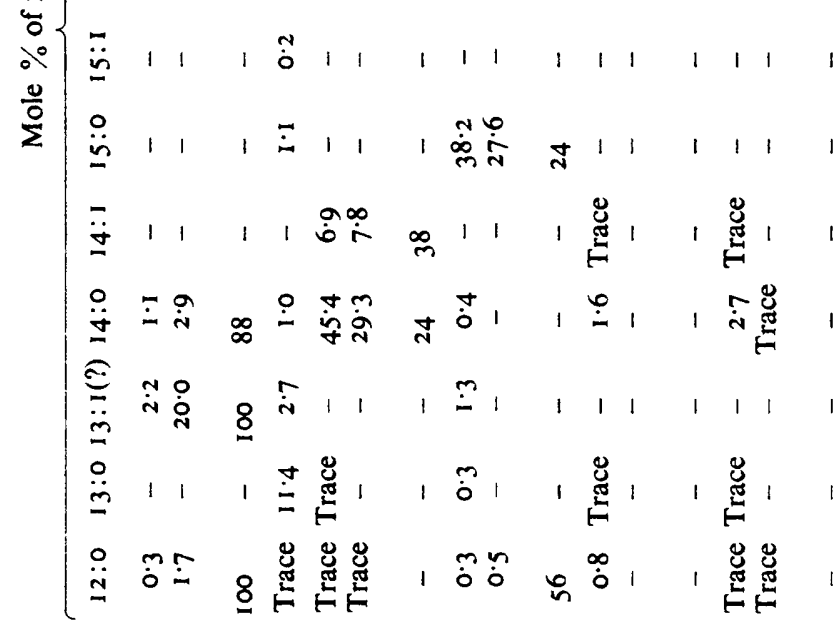
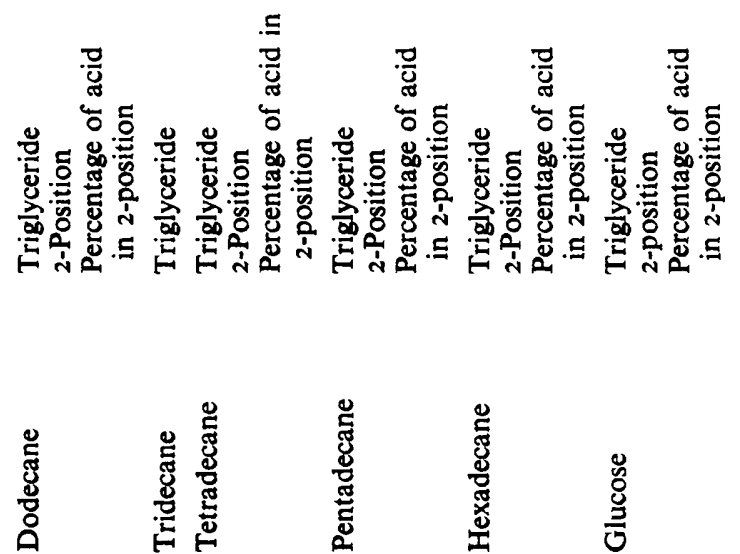
Table 6. Calculated triglyceride compositions of

Candida 107 grown on n-alkanes

Derived from data given in Table 5.

\begin{tabular}{lrrrrrr} 
& \multicolumn{6}{c}{ Triglyceride fraction* } \\
\cline { 2 - 7 } & SSS & SSU & SUS & USU & SUU & UUU \\
Dodecane & I.0 & $6 \cdot 0$ & $5 \cdot 3$ & $8 \cdot 3$ & $31 \cdot 8$ & $48 \cdot 0$ \\
Tetradecane & $18 \cdot 9$ & $22 \cdot 9$ & $22 \cdot 1$ & $6 \cdot 2$ & $28 \cdot 5$ & $1 \cdot 4$ \\
Pentadecane & $13 \cdot 1$ & $12 \cdot 3$ & $34 \cdot 5$ & $2 \cdot 8$ & $30 \cdot 5$ & $6 \cdot 8$ \\
Hexadecane & I.7 & $8 \cdot 8$ & $6 \cdot 0$ & $11 \cdot 5$ & $31 \cdot 7$ & $40 \cdot 3$ \\
Glucose & $2 \cdot 6$ & $1 \cdot 6$ & $61 \cdot 2$ & $0 \cdot 1$ & $30 \cdot 8$ & $6 \cdot 3$ \\
& * Designations as given in Table 3.
\end{tabular}

Table 7. Yield and lipid content of Candida tropicalis grown on individual $n$-alkanes in a vortex fermenter for 5 days

\begin{tabular}{|c|c|c|c|c|c|c|c|}
\hline \multirow[b]{2}{*}{ Substrate } & \multirow[b]{2}{*}{$\begin{array}{r}\text { Yield of } \\
\text { biomass } \\
\text { (g dry wt/l) }\end{array}$} & \multirow[b]{2}{*}{$\begin{array}{c}\text { Total } \\
\text { lipid } \\
\text { (\% dry wt) }\end{array}$} & \multirow[b]{2}{*}{$\begin{array}{l}\text { Total lipid } \\
\text { intracellular } \\
\text { hydrocarbon } \\
(\% \text { dry wt) }\end{array}$} & \multicolumn{4}{|c|}{$\begin{array}{l}\text { Relative percentage composition of lipid after } \\
n \text {-alkane removal }\end{array}$} \\
\hline & & & & $\begin{array}{l}\text { Sterol } \\
\text { esters }\end{array}$ & $\begin{array}{c}\text { Triglycerides } \\
\text { + free } \\
\text { fatty acids }\end{array}$ & 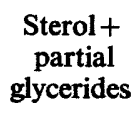 & Phospholipids \\
\hline Dodecane & $6 \cdot 4$ & 0.8 & 0.8 & 9 & 26 & 44 & $2 I$ \\
\hline Tridecane & $6 \cdot 9$ & 14.7 & $2 \cdot 4$ & 13 & 35 & 28 & 24 \\
\hline Tetradecane & $9 \cdot 2$ & $5 \cdot 9$ & $1 \cdot 9$ & 9 & 36 & 30 & 25 \\
\hline & $10 \cdot 1$ & $16 \cdot 4$ & $2 \cdot 3$ & 2 & 20 & 26 & 52 \\
\hline Hexadecane & $10 \cdot 4$ & 17.9 & $6 \cdot 3$ & 3 & $5 I$ & 20 & 26 \\
\hline
\end{tabular}

the trigylceride fraction (53\% and $50 \%$ respectively). Although this particular triglyceride fraction has only previously been found in considerable proportions in seed oils such as cocoa butter and illipé butter (Coleman, 1963; Jurriens, I968), in which over $60 \%$ of the total triglyceride acids are saturated acids (Coleman, 196I; Coleman, 1963), there is no reason to assume that other yeasts containing a similarly high content of saturated acids would not likewise have a high proportion of this particular triglyceride fraction. Unfortunately, few yeasts contain more than about 20 to $30 \%$ saturated acids (see Shaw, I966; Johnson \& Brown, 1972; Johnson, Nelson \& Brown, 1972) and of the yeasts that are 'oleaginous' (a term usually applied to vegetable seeds or fruit implying an oil content of at least 15 to $20 \%$; Fedeli \& Jacini, 1971) Candida 107 seems unique in this respect. Rhodotorula gracilis, considered to be one of the highest fat-yielding yeasts (Woodbine, 1959), contains only at best about $30 \%$ saturated acids (Kessell, I968). Some other species of Rhodotorula, including R. graminis studied here, do, however, contain a much higher proportion of saturated acids (Holmberg, I948; Bass \& Hospodka, I952; Hartman, Hawke, Shorland \& diMenna, 1959) but do not have as high a lipid content as $R$. gracilis (Woodbine, I959; Hunter \& Rose, 1971).

When grown on $n$-alkanes, Candida 107 and $C$. tropicalis produced less lipid than when grown on glucose but this may only be a reflexion of method of cultivation as lipid contents higher than those obtained when grown on glucose have already been reported for Candida I07 grown in a stirred fermenter (Ratledge, 1968). The increase in phospholipids in alkanegrown yeasts compared with glucose-grown yeasts probably reflects differences in membrane 


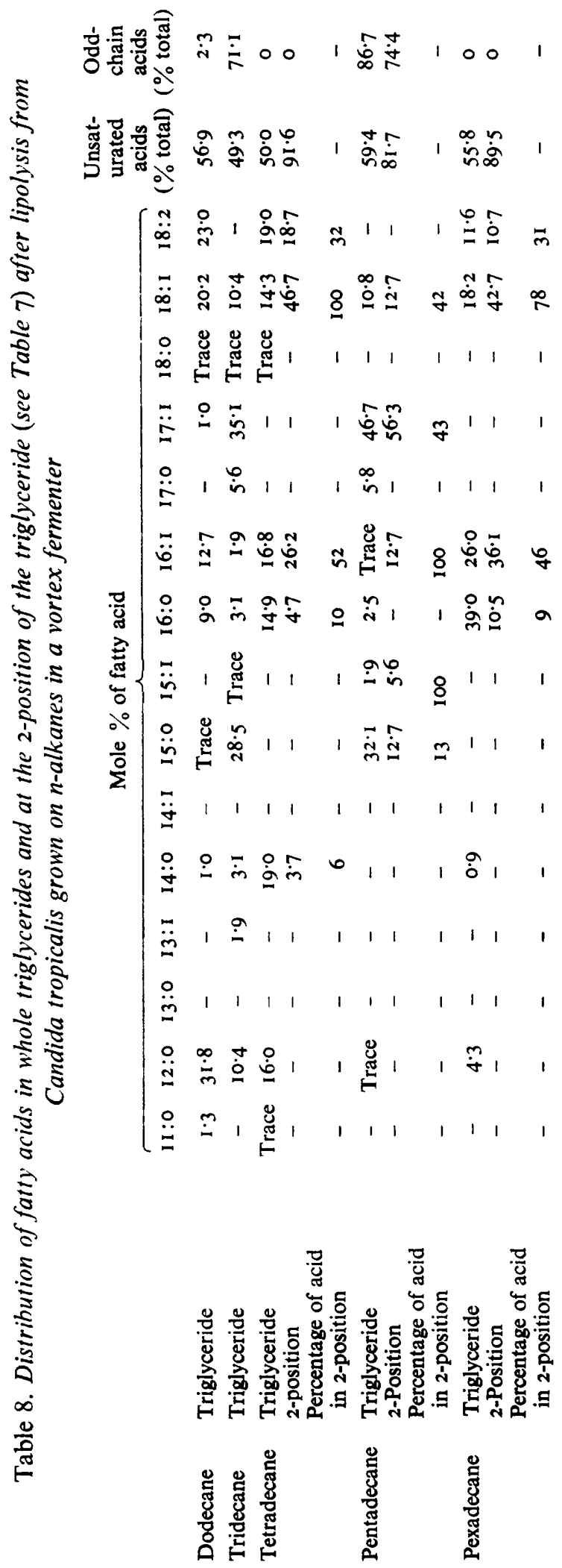


Table 9. Calculated triglyceride compositions of

Candida tropicalis grown on n-alkanes

Derived from data given in Table 8.

\begin{tabular}{lcccccc} 
& \multicolumn{6}{c}{ Triglyceride fraction* } \\
\cline { 2 - 7 } \multicolumn{1}{c}{ Substrate } & SSS & SSU & SUS & USU & SUU & UUU \\
Tetradecane & $3 \cdot 6$ & $3 \cdot 0$ & $46 \cdot 5$ & $0 \cdot 6$ & $38 \cdot 2$ & $8 \cdot 1$ \\
Pentadecane & $4 \cdot 5$ & $9 \cdot 0$ & $21 \cdot 0$ & $4 \cdot 5$ & $41 \cdot 0$ & $20 \cdot 0$ \\
Hexadecane & $3 \cdot 7$ & $4 \cdot 6$ & $33 \cdot 4$ & $1 \cdot 6$ & $43 \cdot 0$ & $13 \cdot 7$ \\
& $*$ Designations as in Fig. 3. & &
\end{tabular}

Table Io. Comparison of calculated triglyceride composition (from lipolysis data) and experimental triglyceride composition after separation of triglycerides according to number of double bonds present by $\mathrm{AgNO}_{3}$-thin-layer chromatography

\begin{tabular}{|c|c|c|c|c|c|c|c|c|c|}
\hline \multicolumn{5}{|c|}{$\begin{array}{l}\text { Candida } 107 \text { grown on glucose } \\
\text { in vortex fermenter }\end{array}$} & \multicolumn{5}{|c|}{$\begin{array}{l}\text { Candida } 107 \text { grown on } n \text {-tetradecane } \\
\text { in vortex fermenter }\end{array}$} \\
\hline \multicolumn{3}{|c|}{ Calculated $(\%)$} & \multicolumn{2}{|c|}{ Experimental (\%) } & \multicolumn{3}{|c|}{ Calculated (\%) } & \multicolumn{2}{|c|}{ Experimental (\%) } \\
\hline SSS & $2 \cdot 6$ & & SSS & 5 & SSS & & 18.9 & SSS & 23 \\
\hline $\begin{array}{l}\text { SOS } \\
\text { SSO }\end{array}$ & $\left.\begin{array}{r}42 \cdot 0 \\
1 \cdot 6\end{array}\right\}$ & $43 \cdot 6$ & $\left.\begin{array}{l}\text { SOS } \\
\text { SSO }\end{array}\right\}$ & 45 & $\begin{array}{l}\text { SOS } \\
\text { SSO }\end{array}$ & $\left.\begin{array}{r}18 \cdot 0 \\
2 \cdot 9\end{array}\right\}$ & 20.9 & $\left.\begin{array}{l}\text { SOS } \\
\text { SSO }\end{array}\right\}$ & 19 \\
\hline $\begin{array}{l}\text { SOO } \\
\text { SLS } \\
\text { OSO }\end{array}$ & $\left.\begin{array}{r}21 \cdot 2 \\
19 \cdot 2 \\
0.1\end{array}\right\}$ & 40.5 & $\left.\begin{array}{l}\text { SOO } \\
\text { SLS } \\
\text { OSO }\end{array}\right\}$ & 32 & $\begin{array}{l}\text { OSO } \\
\text { SOO } \\
\text { SLS } \\
\text { SSL }\end{array}$ & $\left.\begin{array}{r}0 \cdot 1 \\
2 \cdot 8 \\
4 \cdot I \\
18 \cdot 4\end{array}\right\}$ & $25 \% 4$ & $\left.\begin{array}{l}\text { OSO } \\
\text { SOO } \\
\text { SLS } \\
\text { SSL }\end{array}\right\}$ & 20 \\
\hline $\begin{array}{l}\text { OOO } \\
\text { SLO }\end{array}$ & $\left.\begin{array}{l}2 \cdot 6 \\
9 \cdot 6\end{array}\right\}$ & $12 \cdot 2$ & $\left.\begin{array}{l}\text { OOO } \\
\text { SLO }\end{array}\right\}$ & I2 & $\begin{array}{l}\text { OOO } \\
\text { SOL } \\
\text { SLO }\end{array}$ & $\left.\begin{array}{r}0.4 \\
17.5 \\
2.6\end{array}\right\}$ & 20.5 & $\left.\begin{array}{l}\text { OOO } \\
\text { SOL } \\
\text { SLO }\end{array}\right\}$ & 22 \\
\hline & & & & & $\begin{array}{l}\text { SLL } \\
\text { LSL } \\
\text { LLL }\end{array}$ & $\left.\begin{array}{l}4 \cdot 0 \\
6 \cdot 1 \\
1 \cdot 0\end{array}\right\}$ & $14 \cdot I$ & *Others & 16 \\
\hline
\end{tabular}

* Denotes triglycerides having four or more double bonds.

Designations of triglycerides as given in Table 3 ; additionally triglycerides including ' $O$ ' and ' $L$ ' indicate the presence of oleic and linoleic acids, respectively, in the positions indicated.

structures. Alkane-grown yeasts have deep invaginations in the cytoplasmic membrane (Ludvik, Munk \& Dostalek, 1968) and therefore a higher amount of phospholipids will be needed to maintain its integrity. The wide variation in fatty acid composition in the alkanegrown yeasts can be seen as an attempt to produce triglycerides with acceptable physiolological properties, such as melting point, crystal structure and mutual solubilities, to be stored within the fat vacuoles of the yeast. With these substrates, both yeasts contained a significant proportion of triglycerides in which the 2-position was occupied by a saturated acid. This was most evident for Candida 107 grown on $n$-tetradecane and $n$-pentadecane, where, although the proportion of unsaturated acids was the same as that when glucose had been used as carbon source, $46 \%$ and $28 \%$ respectively of the total triglycerides contained a saturated acid in the 2-position. In this respect, the various triglyceride fractions were similar in proportion to those observed in animal fats such as beef tallow (Vander Wal, 1960). Such a commodity has a much lower commercial value than that of many vegetable oils, particularly cocoa and illipé butters (Ratledge, 1970). 
As the quality and amount of the triglycerides from the two yeasts grown on $n$-alkanes were less than when the yeasts had been grown on glucose, the main advantage to be gained by growing yeasts on $n$-alkanes is, as far as lipid formation is concerned, the biosynthesis of specific fatty acids rather than the production of plant-like triglycerides.

We thank the Science Research Council for a C.A.P.S. award to R.F.T. and thank British Petroleum Company Ltd for their co-operation with this studentship. Dr J. D. Levi of B.P. Proteins Ltd, Grangemouth Division, is thanked for his interest in this work.

\section{REFERENCES}

Barrett, C. B., Dallas, M. S. J. \& Padley, F. B. (1962). Separation of isomeric mixed triglycerides by thin layer chromatography using silica gel $\mathbf{G}$ impregnated with $\mathrm{AgNO}_{3}$. Chemistry and Industry, 1050-1051.

Barron, E. J. \& Hanahan, D. J. (1958). Observations on the silicic acid chromatography of the neutral lipids of rat liver, beef liver, and yeast. Journal of Biological Chemistry 231, 493-503.

BAss, A. \& HospodKA, J. (1952). Biosynthesis of fats by yeast. II. Composition of fat at various temperatures. Chemicke Listy 46, 243-245.

Coleman, M. H. (196I). Further studies on the pancreatic hydrolysis of some natural fats. Journal of American Oil Chemists' Society 38, 685-688.

Coleman, M. H. (1963). The structural investigation of natural fats. Advances in Lipid Research 1, 26-64.

Coleman, M. H. \& Fulton, W. C. (1961). The structural investigation of natural fats by the partial hydrolysis technique. In Enzymes of Lipid Metabolism, pp. 127-137. Edited by P. Desnuelle. New York: Pergamon Press.

DAvis, J. B. (1964). Microbial incorporation of fatty acids derived from $n$-alkanes into glycerides and waxes. Applied Microbiology 12, 210-214.

Desnuelle, P., Sari, H. \& EnTressangles, B. (1966). Positional specificity of pancreatic lipase. Biochimica et biophysica acta 125, 597-600.

FEDELI, E. \& JACINI, G. (1971). Lipid composition of vegetable oils. Advances in Lipid Research 9, 335-382.

Folch, J., Lees, M. \& Sloane-Stanley, G. H. (1957). A simple method for the isolation and purification of total lipids from animal tissues. Journal of Biological Chemistry 226, 497-509.

HARRIes, P. C. \& RATLEDGe, C. (1969). Distribution of fatty acids in triglyceride from a yeast species grown on a fraction of $n$-alkanes predominant in tridecane. Chemistry and Industry 582-583.

Hartman, L., Hawke, J. C., Shorland, F. B. \& diMenna, M. E. (1959). The fatty acid composition of Rhodotorula graminis fat. Archives of Biochemistry and Biophysics 81, 346-352.

HarveY, N. L., Fewson, C. A. \& Holms, W. H. (1968). Apparatus for batch culture of microorganisms. Laboratory Practice 17, $1134-1136$.

Holmberg, J. (1948). Yeast lipids. I. The component acids of Rhodotorula gracilis fat. Svensk Kemisk Tidskrift $\mathrm{x}, 14-20$.

Hunter, K. \& Rose, A. H. (197I). Yeast lipids and membranes. In The Yeasts, vol. II, pp. 2 I I-270. Edited by A. H. Rose \& J. S. Harrison. London: Academic Press.

Johnson, B. \& Brown, C. M. (1972). A possible relationship between the fatty acid composition of yeasts and the petite mutation. Antonie van Leeuwenhoek (in the Press).

Jornson, B., Nelson, S. J. \& Brown, C. M. (1972). Influence of glucose concentration on the physiology and lipid composition of some yeasts. Antonie van Leeuwenhoek (in the Press).

JURRIENs, G. (1968). Analysis of glycerides. In Analysis and Characterisation of Oils, Fats and Fat Products, vol. II, pp. 217-298. Edited by H. A. Boekenoogen. London: Interscience.

Kesselu, R. H. J. (1968). Fatty acid of Rhodotorular gracilis: fat production in submerged culture and the particular effect of pH value. Journal of Applied Bacteriology 3I, 220-23I.

Ludvik, J., Munk, V. \& Dostalek, M. (1968). Ultrastructural changes in the yeast Candida lipolytica caused by penetration of hydrocarbons into the cell. Experientia 24, 1066-1068.

MARINETTI, G. (1962). Chromatographic separation, identification and analysis of phosphatides. Journal of Lipid Research 3, 1-20.

Nichols, B. W. \& JAmEs, A. T. (1964). The lipids of plant storage tissue. Fette, Seifen, Anstrichmittel 66, $1003-1006$. 
Ratledge, C. (1968). Production of fatty acids and lipid by a Candida sp. growing on a fraction of $n$-alkanes predominating in tridecane. Biotechnology and Bioengineering ro, $51 \mathrm{I}-533$.

RATLEDGE, C. (1970). Microbial conversions of $n$-alkanes to fatty acids: a new attempt to obtain economical microbial fats and fatty acids. Chemistry and Industry 843-854.

RATLEDGE, C. (197I). The industrial potential of microbial lipids. Journal of General Microbiology 68, xxiii.

SHAw, R. (1966). The polyunsaturated fatty acids of microorganisms. Advances in Lipid Research 4, 107-1 74.

STERN, I. \& SHAPIRO, B. (1953). A rapid and simple method for the determination of esterified fatty acids and for total fatty acids in blood. Journal of Clinical Pathology 6, 158-160.

Thomas, A. E., Scharoun, J. E. \& Ralston, H. (1965). Quantitative estimation of isomeric monoglycerides by thin-layer chromatography. Journal of American Oil Chemists' Society 42, 789-792.

VANDER WAL, R. J. (1960). Calculation of the distribution of the saturated and unsaturated acyl groups in fats, from pancreatic lipase hydrolysis data. Journal of American Oil Chemists' Society 37, 18-20.

VANDER WAL, R. J. (1964). Triglyceride structure. Advances in Lipid Research 2, I-I6.

WILLS, E. D. (1965). Lipases. Advances in Lipid Research 3, 197-240.

WoodBIne, M. (1959). Microbial fat: microorganisms as potential fat producers. In Progress in Industrial Microbiology, vol. I, pp. 18I-245. Edited by D. J. D. Hockenhull. London: Heywood \& Co. 